\title{
The Mulberry, Morus alba (L.): The Medicinal Herbal Source for Human Health
}

\author{
Rutuja Ashok Kadam ${ }^{1 *}$, Nivedita Dattatray Dhumal ${ }^{1}$ and \\ Vitthalrao Bhimasha Khyade ${ }^{2,3,4}$
}

${ }^{1}$ Department of Home Science, Shardabai Pawar Mahila Mahavidyalaya, Shardanagar Tal. Baramati District, Pune - 413115, India

${ }^{2}$ A Sericulture Unit, Malegaon Sheti Farm, Agricultural Development Trust Baramati, Shardanagar, (Malegaon Khurd) Post Box No - 35, Baramati, Pune 413 115, Maharashtra, India

${ }^{3}$ Department of Zoology, Baramati Dist. Pune - 413115 (India Shardabai Pawar Mahila Mahavidyalaya, Shardanagar Tal), India

${ }^{4}$ Dr. APIS, Shrikrupa Residence, Teachers Society, Malegaon Colony (Baramati) Dist.

Pune - 413115, India

*Corresponding author

\section{Keywords}

Antioxidants, Mulberry, Morus alba (L.), Cancer, diabetes,

Deoxynojirimycin

Article Info

Accepted:

20 March 2019

Available Online:

10 April 2019

\section{A B S T R A C T}

Nutrient contents in the leaves of mulberry, Morus alba (L) made it to occupy the pace making place in the sericultural practices. The mulberry, Morus alba (L.) is native to eastern and central China. It became naturalized in Europe centuries ago. The tree was introduced into America for silkworm culture in early colonial times and naturalized and hybridized with the native red mulberry. The red or American mulberry is native to eastern United States from Massachusetts to Kansas and down to the Gulf coast. The black mulberry is native to western Asia and has been grown for its fruits in Europe since before Roman times. It is a flowering, fast growing, woody and perennial plant. Taxonomically, it belongs to the family: Moraceae. Mulberry, Morus alba (L.) gained attention since time immemorial. This is due to its pharmacological and economic value. Use of mulberry leaves in sericulture has been reported in the ancient Chinese literature and therefore well recognized. Therapeutic Significance of Mulberry, Morus alba (L.) have been depicted in the ancient literature through Ayurveda. Some of the ayurvedic therapeutic preparations use fruits, leaves, roots, bark or latex of mulberry, Morus alba (L.) to administer against various human diseases. The raw mulberry fruits, of about $100 \mathrm{~g}$ are able to provide $180 \mathrm{~kJ}$ (43 kcal), $44 \%$ of the Daily Value (DV) for vitamin C, and 14\% of the DV for iron; and other nutrients. The health benefits of mulberry, Morus alba (L.) include their ability to improve digestion, lower cholesterol, help in weight loss, increase blood circulation, build bone tissues, and boost the immune system. The fruits of mulberry, Morus alba (L.) also helps prevent certain cancers, slow down the aging process, lower blood pressure, protect eyes, and improve the overall body metabolism. The present attempt is a overview of the major pharmacological properties of Mulberry, Morus alba (L.) along with major applications of phytochemicals purified from it. 


\section{Introduction}

Herbal contents are serving a lot to orchestrate the progression of development of faculty of Medicine. Human being trusts effective and time-tested home remedies that have survived for several generations. Human being is turning towards the herbal supplements than ever before. The person living in a medicated nation does not like to take the risk of side effect induced prescription drugs. The society is now looking for alternative ways of preventing any diseases or ailments. The herbal preparation from medicinal plants is the one of the humanity's oldest and wealthy health care tools. The herbal formulations are serving as the basis of modern medicines, Ancient civilizations relied on herbs and medicinal plants for healing, as do many contemporary culture throughout the world. According to the World Health Organization, near about eighty percent of the population of the world continues to use complimentary therapies, a major part of which are derived from the plants like, mulberry, Morus alba (L.). The mulberries are the sweet, hanging fruits from a genus of deciduous trees that grow in a variety of temperate areas around the world. Thought to possibly have originated in China, they have spread throughout the world and are highly praised for their unique flavor and impressive composition of nutrients. In fact, most varieties found in different parts of the world are considered to be "native" from those areas, as they are widespread. The scientific name of mulberries varies depending on which species you are looking at, the most common types are Morus australis and Morus nigra, but there are other delicious varieties as well. In terms of appearance, the berries grow very fast when they are young but gradually slow as their color changes from white or green to pink or red, and eventually settling on dark purple or even black. The sweet or tart flavor makes these berries ideal for sherbets, jams, jellies, fruit tarts, pies, wines, teas, and cordials. In certain areas of the world, the flavors of the mulberry varieties differ, but the American mulberry and the black mulberry are considered to have the most powerful flavor and are widely sought after. Interestingly, the mulberry tree has another important resource, besides providing people with delicious berries and that is its leaves. The mulberry leaves are also the only known food source for silkworms.

The mulberry, Morus alba (L.) is also recognized as white mulberry. It is a fastgrowing, small to medium-sized mulberry tree which grows to $10-20 \mathrm{~m}$ tall. The species, Morus alba (L.) is native to northern China. It is widely cultivated and naturalized elsewhere (United States, Mexico, Australia, Kyrgyzstan, Argentina, etc.). The genus Morus contains more than 15 species of deciduous plants commonly called mulberry. The major ones include Morus alba, Morus nigra, Morus rubra, Morus australis, Morus atropurpurea, Morus cathayana, Morus notabilis and Morus mesozygia. These are economically important plant because the leaves are extensively used in sericulture. Mulberries are filled with nutrients that are important for our body, including iron, riboflavin, vitamin $\mathrm{C}$, vitamin $\mathrm{K}$, potassium, phosphorous, and calcium. They also contain a significant amount of dietary fiber and a wide range of organic compounds, including phytonutrients, zeaxanthin, resveratrol, anthocyanins, lutein, and various polyphenolic compounds. Apart from this, many nutritional benefits and medicinal values are attributed to this plant. The leaves contain high amount of protein and the nutritional scientists in India suggested the use of dry leaf powder for making parathas, one of the most popular Indian food items. In Korea and Japan the mulberry leaves and fruits are included in their functional foods, 
used in the preparation of tea (Fig. 1 and 2) and ice creams. This plant has remarkable effects in lowering serum glucose and blood cholesterol levels enabling their use in traditional Chinese herbal and folk medicines. These properties are due to the presence of many bioactive components such as flavonoids, polyphenols, alkaloids, terpenoids, steroids etc. in this plant (Scrivastava, et al., 2003; Andallu and Varadacharyulu, 2003; Asano, et al., 2001). Different parts (root bark, stem bark, leaves and fruits) of the mulberry, Morus alba (L.) have been extensively investigated for their various health benefits, including antioxidative, hypolipidemic, antihyperglycemic, and antiatherogenic effects (Harauma et al., 2007). The present review focuses on the antioxidant activity and medicinal properties of mulberry, Morus alba (L.) responsible for its therapeutic utilization, with special emphasis on major bioactive principles from its different parts. The parameters considered for the present attempt of review on therapeutic Significance of Mulberry, Morus alba (L.) include: Antioxidative Potentials of mulberry, Morus alba (L.); Antidiabetic Significance of mulberry, Morus alba (L.); The mulberry, Morus alba (L.) for cardiovascular diseases; Anticancer effects of mulberry, Morus alba (L.); Anti-inflammatory effects of mulberry, Morus alba (L.); The mulberry, Morus alba (L.) for neurological disorders; The mulberry, Morus alba (L.) for skin diseases; Hepatoprotective Potentials of mulberry, Morus alba (L.); The mulberry, Morus alba (L.) for gastrointestinal disorders and Antimicrobial effects of mulberry, Morus alba (L.).

Antioxidative potentials of mulberry, Morus alba (L.)

Presence of wide array of phytochemicals in different parts accounts for the antioxidative potential of mulberry, Morus alba (L.). The fruits of mulberry, Morus alba (L.) are considered as nutritious food. This is because, the fruits of mulberry, Morus alba (L.) contain flavonoids and polyphenols. The most important flavonoids and polyphenols identified from mulberry, Morus alba (L.) are apigenin, luteolin, quercetin, morin, caffeic acid, gallic acid, rutin, umbelliferone, chlorogenic acid and kaempferol (Arfan, et al., 2012 and Chu, et al., 2006). The compounds like maclurin, rutin, isoquercitrin, resveratrol and morin belong to the twigs and root bark of mulberry, Morus alba (L.) (Chang, et al., 2011). The fruits of mulberry, Morus alba (L.) contains essential fatty acids like palmitic, oleic and linoleic acids which are important for cell membrane formation, proper development and functioning of nervous system, production of eicosanoids and many inflammatory responses (Ercisli and Orhan, 2007). Morus cathayana (L.) is one more species of mulberry. This Morus cathayana (L.) is a deciduous tree usually found in secondary forest and scrubland. The tree of mulberry, Morus cathayana (L.) reaches a height of up to 15 metres (49 feet). It use to flower from May to June. It produces edible berries and its leaves are made into a tea. The phytochemical investigation of the stem bark of mulberry, Morus cathayana (L.) led to the isolation and identification of cathayanin and various cathayanons $(\mathrm{Ni}$, et al., 2010). Few arylbenzofurans with antioxidant and anti-inflammatory activities were reported form $M$. wittiorum (Tan, et al., 2010). HPLC coupled with UV absorption detection lead to the identification of five important stilbene glycosides from mulberry, Morus alba (L.) (Piao, et al., 2011). Benzokuwanon E, hydroxymorusin, dicyclokuwanon EA, and dicyclokuwanon EB are the important flavonoids isolated from Morus australis (L.) and their structures were elucidated on the basis of UV, IR, MS, NMR, and CD spectral data (Zheng, et al., 2012). 
The aqueous extractives the leaves of mulberry, Morus alba (L.), prepared at high temperature was reported to contain four important flavonols, quercetin-3-ß-D-glucose, quercetin-3-O-glucose-6?-acetate, rutin and quercetin (Kim and Jang, 2011). The lupeol type pentacyclic triterpenoids separated from the stem bark of mulberry, Morus alba (L.) include: moruslupenoic acid A, moruslupenoic acid $\mathrm{B}$ and moruslanosteryl acetate (Ali and Ali, 2012). The aqueous methanolic extract of the root bark of mulberry, Morus alba (L.) yields the compound "Moran 20K". The Moran $20 \mathrm{~K}$ is a glycoprotein with antioxidant antidiabetic activity (Kim, 1999). 1-deoxynojirimycin (DNJ), resveratrol, oxyresveratrol, cyanidin3-O-betaglucoside (Cy-3-glu), cyanidin-3-Obeta-rutinoside ( $\mathrm{Cy}$-3-rut), and rutin were also reported in different species of mulberry (Song, et al., 2009). The compounds like sanggenol, kuwanon, moracin, mulberrofuran, mulberroside, 1-deoxynojirimycin, 2-Oalpha-Dgalactopyranosyl$1-$ deoxynojirimycin, fagomine, betulinic acid, ursolic acid and beta-sitosterol are the important chemical constituents of the root bark of mulberry, Morus atropurpurea (L.). Kumar, et al., 2008 and Butt, et al., (2008) the literature on the major pharmacologically important compounds from mulberry, Morus alba (L.) and other species of mulberry. Vitthalrao B. Khyade, et al., (2013, 2014. $2015,2015,2018$ ) assed the capabilities of moracin as antioxidant and reported it as ideal herbal compound to prevent oxidative stress. The potential regarding antioxidant activity of Moracin, the novel compound belong to mulberry was assessed through the use of hydrogen peroxide induced stress in skin fibroblast cell line culture (AH927) by Vitthalrao B. Khyade et al., (2018). The results of this attempt showed that the Moracin offers protection against oxidative stress. And cell viability was found restored to that of control on pre-incubation with the
Moracin. The fibroblasts pre-incubated with Moracin had significantly lower levels of catalase; lactate dehydrogenase and malondialdehyde activity when compared to untreated ones. The acetone-soluble (and water soluble too) Moracin, from a natural source, the fruits of mulberry, Morus alba (L), serve as ideal molecule to prevent oxidative stress.

\section{Antidiabetic significance of mulberry, Morus alba (L.)}

The Diabetes mellitus is a group of metabolic disorders. It is characterized by high blood sugar (glucose) levels. This high blood sugar (glucose) levels is in response to the defects in insulin secretion, or its action, or both. The disease diabetes mellitus was first identified as a disease associated with "sweet urine," and excessive muscle loss in the ancient world. Increased levels of blood glucose (which may also called as hyperglycemia) lead to spillage of glucose into the urine, hence the term sweet urine. Normally, in healthy body, the blood glucose levels are tightly controlled by insulin, a hormone produced by the pancreas. Insulin lowers the blood glucose level. When the blood glucose elevates (for example, after eating food), insulin is released from the pancreas to normalize the glucose level by promoting the uptake of glucose into body cells. In diabetic patients, the absence of insufficient production of or lack of response to insulin causes hyperglycemia. The Diabetes mellitus is thus characterized by sustained hyperglycemia. It is associated with many secondary complications in the body metabolism. The secondary complications through diabetes mellitus include: formation of free radicals and non enzymatic glycosylated end products. This situation is responsible for higher oxidative stress and vascular complications (Ahmed, 2000; Baynes and Thorpe, 2000). Naowaboot et al., 
(2009) reported the antihyperglycemic, antioxidant and antiglycation activities of extractives of leaves of mulberry, Morus alba (L.) in streptozotocin induced chronic diabetic rats. The leaves of mulberry, Morus alba (L.) are one of the important herbal medicines used for the treatment of hyperglycemia. It was proved by experiments in animal models that mulberry leaf extract possess antihyperglycemic, antioxidant and antiglycation activities (Naowaboot, et al., 2009). The extractive of the leaves of mulberry, Morus alba (L.) is reported as effective in modulating the nitric oxide synthase expression in the hypothalamus of streptazotocin treated rats (Jang, et al., 2002). The red mulberry, Morus rubra (L.) is a species of mulberry native to eastern and central North America. The leaf extractives of this red mulberry, Morus rubra (L.) exerts its antidiabetic activity in streptazotocin induced diabetic rats by decreasing the fasting glucose levels, glycosylated haemoglobin and increasing the plasma insulin and C-peptide levels Sharma, et al., 2010). The credit of antidiabetic activity of mulberry, Morus alba (L.) goes to its novel compound: 1Deoxynojirimycin (DNJ). This 1Deoxynojirimycin (DNJ) has been shown to inhibit intestinal a-glucosidases, which results in reduction of blood glucose (Hansawasdi, et al., 2006). According to Li, et al., (2011), a hybrid of 1- Deoxynojirimycin (DNJ) and a polysaccharide helps in regulating the expression of the hepatic gluconeogenic enzymes, glucokinase, PEP carboxykinase and glucose 6-phosphatse. The polysaccharide in this mixture is able to protect pancreatic islets from alloxan induced damge, repair the destroyed pancreatic islets, upregulate the PDX-1, insulin-1 and insulin-2 expression in pancreas and normal secretion of insulin in serum. Taniguchi, et al., (1998) fagomine contents in the leaves of mulberry, Morus alba (L.). Fagomine of mulberry leaves is capable of inducing insulin secretion in isolated rat islet cells. In patients with type 2 diabetes, mulberry treatment caused an improvement in glycemic control and fall in VLDL production. Also it decreased the lipid peroxidation in blood, urine and $\mathrm{RBC}$ membrane (Andallu et al., 2001). The moracin M; steppogenin-4'-O-B-D-glucosiade and mullberroside- $\mathrm{A}$ were also isolated from the root bark of mulberry, Morus alba (L.). All the three flavones (moracin $\mathrm{M}$; steppogenin-4'-O-B-D-glucosiade and mullberroside-A) exhibited hypoglycemic effect in alloxan induced diabetic mice (Zhang, et al., 2009). There is important role of a-amylase, the key enzyme catalyzes the initial step in the hydrolysis of starch to smaller oligosaccharides. Retardation of starch digestion by inhibition of a-amylase, the key enzyme catalyzes the initial step in the hydrolysis of starch to smaller oligosaccharides plays a key role in the control of diabetes. The extractives of leaves of mulberry, Morus alba (L.) rich in tannins, flavonoids, cardiac glycosides and saponins exhibit significant a-amylase inhibitory activity (Sudha et al., 2011).

The insulin resistance and low grade chronic inflammatory status are the distinguishing features of type 2 diabetes. The secondary complication associated with type 2 diabetes is the development of cardiovascular diseases. Type 2 diabetic related resistance of insulin depends both on glucose metabolism and fatty acid metabolism (Haffner, 1991). Improvement in insulin resistance has been suggested as an effective way to prevent life style related type 2 diabetes and vascular complications. Repeated ingestion of extractives of leaves of mulberry, Morus alba (L.) reduces the insulin resistance in high fat fed KK-Ay mice (Tanabe, et al., 2011). Kim, et al., (2012) reported improvement in the markers of inflammation and insulin resistance in experimental animal models through the long term provision of extractives 
of leaves of mulberry, Morus alba (L.). The circulating oxidized low density lipoproteins (LDL) was also improved in the treated group, which is often elevated in type 2 diabetes. The extractives of leaves of mulberry, Morus alba (L.) increases the rate of glucose uptake by a direct enhancement of insulin independent glucose transport in skeletal muscle. 5'- AMP-activated protein kinase (AMPK) is the major signaling intermediary in the exercise-stimulated insulin independent glucose transport in skeletal muscle (Musi, et al., 2006). The skeletal muscle AMPK is also implicated in a variety of antidiabetic properties of exercise, including glucose transporter 4 (GLUT4) expression, glycogen regulation, fatty acid oxidation and enhanced insulin sensitivity. Mulberry leaf extract increases the activity of both AMPK a 1 and 2 in skeletal muscles and is associated with insulin independent glucose transport without change in the energy status of the muscle and reduces the risk of type 2 diabetes (Ma, et al., 2009). Decrease in adipogenesis lead to limited storage sites for free fatty acids cause increase in plasma free fatty acids. This increase in circulating free fatty acids result in fat deposition in muscle and liver causing insulin resistance and type 2 diabetes mellitus. Adiponectin is a member of the adipokine family is induced during adipocyte differentiation. Circulating levels of adiponectin will be low in patients having obesity and type 2 diabetes (Nadler, et al., 2000).

The extractives of leaves of mulberry, Morus alba (L.) stimulates differentiation of 3T3-L1 preadipocytes into adipocytes by increasing the expression of adipogenic genes and improve the secretion of adiponectin and insulin sensitivity. This mechanism of action is similar to that of the thiazolidinediones, a class of insulin sensitizing drugs used to treat type 2 diabetes (Naowaboot et al., 2012).
Reduction in the fasting blood sugar, normalization of liver enzymes level and improvement in the lipid profile are reported in the diabetic rats treated with the extractives of leaves of mulberry, Morus alba (L.) (Vitthalrao B. Khyade, 2014).

The treatment of diabetic rats using the decoction leaves of Mulberry, Morus alba (L.) $(20 \mathrm{~g} / \mathrm{L})$ is reported to decrease the blood glucose levels, to inhibit hepatic glycogen loss, and to prevent potential histopathological alterations in the pancreas and kidneys. The provision of leaf decoction of Mulberry, Morus alba (L.) (20 g/L) was found to be able to regulate the altered metabolic processes. The results suggest that Mulberry, Morus alba (L.) leaf decoction $(20 \mathrm{~g} / \mathrm{L})$ is useful for diabetes mellitus management (Vitthalrao B. Khyade, 2018). Mulberry, Morus alba (L.) should be explored as medicinal plant to be used to control the diabetes. Given a reasonable likelihood that medicinal plants with a long history of human use will ultimately yield novel drug prototypes, systematic and intensive search in plants for new drugs to treat Type 2 diabetes mellitus seem to be of a great utility. This approach seems likely to increase the chances for discovering new drugs for the management of diabetes mellitus.

The mulberry, Morus alba (L.) for cardiovascular diseases

The mulberry, Morus alba (L.) has been widely used to prevent and to treat symptoms associated with cardiovascular disease for over a millennium in eastern countries. Aqueous preparations of mulberry, Morus alba (L.) were used in the herbal prescriptions by Chinese people to reduce blood pressure. The leaf extractives of the mulberry, Morus alba (L.) shown to reduce hypertension in rodents and decreases serum cholesterol and prevent atherosclerosis (Doi, et al., 2000 and 
Oh, et al., 2007). The ethyl acetate extractives of mulberry, Morus alba (L) has dual vasoactive effects. The relaxation was mediated by inhibition of voltage- and receptor dependent $\mathrm{Ca} 2+$ channels in vascular smooth muscle cells, while the contraction occurred via activation of ryanodine receptors in the sarcoplasmic reticulum (Xia, et al., 2008). The deoxyribonucleic acid (DNA) micro array analysis were used to investigate gene expression in the livers of hypertriglyceridemic rats treated with mulberry leaves to elucidate the mechanism behind the lipid lowering effect of mulberry. Dietary supplementation increased protein expression of the Carnitine Palmitoyltransferase 1A (CPT1A); Acyl-CoA Oxidase 2 (ACOX2); phytanoyl-CoA hydroxylase (PHYH) and the activity of acylCoA oxidase / dehydrgenase, the rate limiting enzymes of fatty acid oxidation. The genes upregulated by mulberry included the following peroxisome proliferator-activated receptor alpha (PPAR alpha) and or peroxisome proliferator-activated receptor delta (PPAR delta) targets and many of them are involved in fatty acid oxidation. Angiopoietin-like 3 (also known as ANGPTL3), is a protein that in humans is encoded by the ANGPTL3 gene (Conklin, et al., 1999). Mulberry induced down regulation of this ANGPTL3 results in the activation of lipoprotein lipase and enhanced triglyceride hydrolysis. Mulberry administration also upregulated the Glycerol Kinase gene (Gyk gene) and caused a reduction in the plasma non esterified fatty acid level. The StearoylCoA desaturase gene ( $S c d$ gene) is the gene involved in lipogenesis and this gene was down regulated after treatment with mulberry which inhibits lipogenesis and facilitates fatty acid oxidation (Kobayashi, et al., 2010). Morus Bombycis is an extract found in mulberries that is often used in cosmetics due to the presence of arbutin, a hydroquinone derivative isolated from the leaves of the bearberry shrub, cranberry, blueberry, some mushrooms, and most types of pears. Morus Bombycis' arbutin can potentially prevent melanin production, Therefore, naturally lightening skin and creating a more youthful appearance (Source). Morus bombycis is also high in antioxidants, and although this property has made it a popular inclusion in the treatment of liver disease and other internal ailments, it is also an effective free radical scavenger. $M$. bombycis root extract exhibited strong anti-lipase activity, with an IC50 value of $2.07 \mu \mathrm{g} / \mathrm{ml}$ in fully differentiated 3T3-L1 adipocytes and adipose tissues. The extract increased lipolytic effects such as decreased intracellular triglyceride and the release of glycerol. Moreover it inhibited phosphodiesterase activity in a dose dependent manner (Kim et al., 2010). So it does have pharmacological applications in metabolic disorders such as obesity. DNJ present in mulberry leaf extract helps in increasing serum adiponectin level, stimulated AMP activated protein kinase to activate $B$ oxidation which inhibits lipid accumulation in liver (Kim, et al., 2010). Mulberry water extract inhibited acetyl coenzyme A carboxylase activities by stimulating AMPK and attenuated the expression of sterol regulatory element binding protein 1 and its target molecules such as fatty acid synthase. In contrast, the lipolytic enzyme expressions of PPAR gamma and carnitine palmitoyltransferase1 were increased $(\mathrm{Ou}$, et al., 2011) (Fig. 3).

Continuous for 12 weeks of provision of the herbal capsules of 1- Deoxynojirimycin (DNJ) rich mulberry leaf extractives for humans reported a modest decrease in serum triglyceride levels and beneficial changes in lipid profile without any side effects (Kojima, et al., 2010). Administration of freeze dried powder of fruits of the mulberry, Morus alba (L.) to rats resulted in a significant decrease in serum and liver triglyceride, total cholesterol, 
serum low-density lipoprotein (LDL) and decrease in atherogenic index. Also an increase in serum high-density lipoprotein (HDL) level, Red Blood Corpuscles (RBC) and liver superoxide dismutase (SOD) level and blood glutathione peroxidase level was observed. The thiobarbituric acid content of serum and liver was reduced indicating the low level of lipid peroxidation (Yang, et al., 2010). Mulberry leaf powder can preserve the cardiac function in experimental autoimmune myocarditis by modulating oxidative stress induced MAPK activation and further afford protection against endoplasmic reticulum stress mediated apoptosis. It significantly decreased oxidative stress, myocyte apoptosis, cellular infiltration, cardiac fibrosis, mast cell density, myocardial levels of sarco/endo plasmic reticulum $\mathrm{Ca} 2+$ ATPase2, p22phox, receptor for advanced glycation end products, phosphor p38 mitogen activated protein kinase, phospho-cJun-NH2-terminal protein kinase, glucose regulated protein78, caspase12 and osteopontin levels (Arumugam, et al., 2013). Morusinol extracted from M.alba root bark significantly inhibited collagen and arachidonic acid induced platelet aggregation and TXB2 formation in cultured platelets. So it is effective in inhibiting arterial thrombosis in vivo due to antiplatelet activity and exerts beneficial effects on transient ischemic attacks or stroke via modulation of platelet activation (Lee, et al., 2012). Some isoprenylated flavonoids with adipogenesis promoting activity were purified from $M$. nigra and M. notabilis (Hu, et al., 2011 and $\mathrm{Hu}$, et al., 2011). The extractives of mulberry, Morus alba (L.) increases the vascular smooth muscle cell migration in a dose dependent manner by inhibiting the activities of MMP-2 and 9, phosphorylation of FAK, protein expression of small GTPases (c-Raf, Ras, Rac1, Cdc42, and RhoA) and NF-kappaB expression (Chan, et al., 2009). Also the extractives of leaves of mulberry, Morus alba
(L.) helps in inhibiting the vascular smooth muscle proliferation by the upregulation of p53 and inhibition of cyclin dependent kinase (Chan, et al., 2010). The high levels of iron content in mulberries can significantly boost the production of red blood cells. This means that the body will increase its distribution of oxygen to important tissues and organs, thereby helping to boost metabolism and optimize the functionality of those systems. Resveratrol is a very important flavonoid that directly affects the functioning of certain mechanisms in blood vessels, primarily making them less prone to damage by angiotensin, which can cause blood vessel constriction. In fact, resveratrol increases the production of nitric oxide, which is a vasodilator. This means that it relaxes blood vessels and reduces chances of blood clot formation and subsequent heart issues like strokes or heart attacks. Resveratrol is found in many dark-skinned berries like mulberries. Because mulberries are high in vitamin $\mathrm{C}$ and flavanoids, they can also help prevent cold and flu-like symptoms, and even treat hepatitis. They are a wonderful dietary addition for post-operative patients, too, since they can speed up recovery via improved blood circulation.

\section{Anticancer effects of mulberry, Morus alba (L.)}

Cancer is a serious public health problem world wide. Most of the natural compounds targets inflammatory pathways and immune modulation for the prevention and treatment of cancer. Mulberry also contains several anticancer compounds. $M$. fructus fruit extract induces cancer cell death in vitro and in vivo. The in vitro effect is due the cell death in an ROS dependent mitochondrial apoptotic pathway (Jeong, et al., 2010). Phenolic compounds from mulberry, Morus alba (L.) induces in vitro anticancer activity in hepatoma cells by cell cycle arrest at G2-M 
phase and inhibition of topoisomerase II activity (Naowaratwattana, et al., 2010). Albanol A (also called as Mulberrofuran G) is the bio-active compound isolated from the root bark of mulberry, Morus alba (L.). This Albanol A was found inducing potent cytotoxicity (IC50 1.7mM) in HL60 cells (Human Leucamia Cell line) through inhibition of topoisomerase II activity (IC50 $22.8 \mathrm{mM}$ ). In addition, it induced early apoptosis through cell death receptor pathway and mitochondrial pathway, observed by membrane phospholipid exposure, reduced levels of pro caspase 3,8 and 9 and increased levels of cleaved caspase 3,8 and 9 and increased bax/BCl2 ratio (Kikuchi, et al., 2010). The anticancer activity of the essential oil separated from mulberry, Morus rotunbiloba Koidz was studied in human larynx epidermoid carcinoma (Hep2) and human colon adenocarcinoma (SW620) cell lines with African green monkey kidney (Vero) cell line as a control. The oil at 0.1 $100 \mu \mathrm{g} / \mathrm{ml}$ had no effect on Vero cell viability. The median lethal concentration (LC50) of the oil on the cytotoxicity of Hep2, SW620 and Vero were 70, 120 and $280 \mu \mathrm{g} / \mathrm{ml}$ respectively (Patharakorn, et al., 2010). Resveratrol, purified from the methanol extract of $M$. alba showed heparinase inhibition and antimetastatic effects on murine B16 melanoma cells (Ahn, 2006). The mulberry, Morus alba (L.) is a rich source of prenylated cytotoxic flavonoids such as sanggenon $\mathrm{J}$ and $\mathrm{K}$, cyclomorusin, morusin, atalantoflavone, kaempferol etc. Henrietta Lacks (August 1, 1920 - October 4, 1951) was an African-American woman whose cancer cells are the source of the HeLa cell line, the first immortalized cell line and one of the most important cell lines in medical research. An immortalized cell line will reproduce indefinitely under specific conditions, and the HeLa cell line continues to be a source of invaluable medical data to the present day. The morusin is the most potent among them. The morusin is with an IC50 value of $0.64 \mu \mathrm{M}$ against HeLa cells (Dat et al., 2010). New 2-arylbenzofuran derivatives (namely moracins of different structure from mulberry, Morus alba (L.) and wittifurans from Morus wittiorum) with potent cytotoxic activity against different human cancer cell lines were identified recently (Yang, et al., 2010 and Tan, et al., 2012). A new galactose binding lectin was also purified from $M$. alba leaves with cytotoxic activity on human breast cancer (IC50-8.5 $\mu \mathrm{g}$ ) and colon cancer cells (IC50-16 $\mu \mathrm{g})$ (Deepa and Priya, 2012) (Fig. 4).

The anthocyanins are a group of phenolic compounds with beneficial effects in reducing the risk of cardiovascular diseases and cancer because of its antioxidant, anti-inflammatory and chemopreventive properties (Middleton, et al., 2000). Cyanidin 3-rutinoside and cyanidin 3-glucoside are the two anthocyanins present in mulberry, Morus alba (L.). They have strong anticancer properties. They have shown to be inhibiting the invasion and migration of human lung cancer A549 cells by downregulating the expression of MMP-2 and urokinase plasminogen activator and enhances the expression of TIMP-2 and plasminogen activator inhibitor. Also an inhibition of the activation of NF-kappa B and c-jun was also observed in this case (Chen, et al., 2006). The osajin is a prenylated isoflavone isolated from the fruit of Maclura pomifera (L.). The tree of Maclura pomifera (L.) and a tree of mulberry, Morus alba (L.), both belong to one and the same family (Moraceae). It exerts multiple effects such as loss of mitochondrial transmembrane potential, release of cytochrome $\mathrm{C}$, expression of Fas ligand, suprresion of glucose regulated protein 78 and activation of various caspsses and propaoptotic proteins in human nasopharyngeal carcinoma cells. So osajin induced apoptosis include extrinsic death receptor pathway and intrinsic pathways 
relying on mitochondria and endoplasmic reticulum (Huang, et al., 2011). Chalcones, a group of aromatic enones from plants, form the central core of a number of biologically important compounds. Investigation on ethanol extract of the leaves of $M$. alba L. yielded two new chalcone derivatives, morachalcone $\mathrm{B}$ and $\mathrm{C}$ with potent cytotoxic effects (Yang, et al., 2010). Flavonids such as sanggenol L, sanggenol $\mathrm{M}$ and different types of mulberrofurans with cytotoxic effects were also purified from M. mongolica (Shi, et al., 2001). Between the high content of anthocyanins, vitamin $\mathrm{C}$, vitamin $\mathrm{A}$, and various other polyphenolic and phytonutrient compounds, mulberries are absolutely packed with antioxidants. Antioxidants are the main line of defense against free radicals, which form a dangerous by-product of cellular metabolism and can damage healthy cells, causing them to mutate into cancerous ones. The diverse range of antioxidants found in mulberries means that they can neutralize these free radicals quickly before too much damage is done.

\section{Anti-inflammatory effects of mulberry, Morus alba (L.) (Fig. 5)}

Mulberry plants have a long history in traditional medicine as anti-inflammatory agents. The root epidermis of mulberry, Morus alba (L.) shown to have antiinflammatory effects (Wang, et al., 2002). The leaves of mulberry, Morus alba (L.) have diaphoretic and emollient effects and are used for making a decoction that can be used as a gargle that throat inflammation. Butanol extract of mulberry, Morus alba (L.) significantly reduced LPS-induced PGE2 production, TNF-alpha and COX-2 expression in RAW264.7 macrophages (Choi, et al., 2005). Methanol extract of mulberry, Morus alba (L.) contains compounds with inducible nitric oxide synthase (iNOS) inhibitory activity which can attribute to its anti-inflammatory properties (Hong, et al., 2002). It exerts antiasthmatic effect in experimental mouse model via enhancement of $\mathrm{CD} 4+\mathrm{CD} 25+$ Foxp3+ regulatory $\mathrm{T}$ cells and inhibition of Th2 cytokines (Kim, et al., 2011). The extract of $M$. bombycis has antiiflammatory and inhibitory effect on collagen induced arthritis. It acts by decreasing the infiltration of immune cells, synovial hyperplasia, cartilage destruction and bone erosion. The mRNA levels of MMP1/3, inflammatory cytokines and chemokines were significantly suppressed, number of osteoclasts were reduced and activation of NF-kappaB and Ap-1 were observed on treatment with the extract (Kim, et al., 2011). The extractives of leaves of mulberry, Morus nigra (L.) and extractives of fruits of mulberry, Morus ihou Koidz are reported for capable of reducing the carrageenan-induced paw edema as well as fibrovascular tissue growth induced by s.c. cotton pellet implantation in animal models indicating its anti-inflammatory property (Kim, et al., 2006 and Padilha, et al., 2010). The cudraflavone B is a prenylated flavonoid found in large amounts in the roots of mulberry, Morus alba (L.) is reported to cause a significant inhibition of inflammatory mediators in selected in vitro models. It was a potent inhibitor of Tumor Necrosis Factor - alpha (TNF alpha) by blocking the translocation of nuclear factor kappa-light-chain-enhancer of activated B cells (NF-kB) from the cytoplasm to the nucleus. The nuclear factor kappa-lightchain-enhancer of activated B cells NF-kB activity reduction resulted in the inhibition of cyclooxygenase 2 (COX-2) gene expression also [74]. (Hosek, et al., 2011). The antiinflammatory compound wittifuran I was purified from the ethanolic extract of stem bark of mulberry, Morus wittiorum (L.) (Tan, et al., 2012). Another compound resveratrol from $M$. alba inhibits IL-8 secretion by blocking mitogen-activated protein kinase (MAPK) phosphorylation and nuclear factor 
kappa-light-chain-enhancer of activated B cells (NF-kappaB) activation in lipopolysaccharide (LPS) induced human monocytic cell line THP-1 (Oh, et al., 2009). Sanggenon $\mathrm{C}$ and $\mathrm{O}$, two Diels-Alder type adducts isolated from $M$. alba, inhibit NO production through the iNOS induction and activation of nuclear factor (NF-kB) in LPSinduced RAW264.7 cells indicating its antiinflammatory potential (Dat, et al., 2012). Several arybenzofurans (moracins and mulberrofurans of different types), prenylated flavonoids (kuwanons, morusin, sanggenon F, betunilic acid etc.) from $M$. alba var. multicaulis Perro showed significant inhibitory activity towards the differentiation of 3T3-L1 adipocytes and inhibition in NO production in RAW264.7 cells (Yang, et al., 2011). Phytochemical fractionation of the methanol extract of $M$. alba root bark lead to the identification of two chalcone derived Diels Alder adducts, kuwanon J trimethylester and kuwanon $\mathrm{R}$ with inhibitory effect on NFkB with IC50 value of 4.65 and $7.38 \mu \mathrm{M}$ respectively (Fung, et al., 2012). Inhibitors of phosphodiesterase -4 (PDE4) enzymes have therapeutic applications as anti-inflammatory agent because inhibition of PDE-4 will lead to the accumulation of cAMP and thus attenuated inflammatory responses in various cell types. Molecular docking studies have shown that moracin $\mathrm{M}$ from $M$. alba can inhibit the activity of a variety of PDE-4 enzymes (Chen, et al., 2012).

\section{The mulberry, Morus alba (L.) for neurological disorders}

Unlike beneficial effect of mulberry in treating diabetes, cardiovascular disease, cancer etc., but its effects on neurological disorders are less studied. The neurotoxicity in Alzheimers disease (AD) is associated with the accumulation of amyloid beta-peptides that forms as a plaque in brain. The methanol extract of mulberry leaves contain compounds such kaempferol -3-O-glucoside, and kaempferol -3-O-(6-malonyl) glucoside which inhibits the formation of amyloid beta-peptide fibrils in vitro, and protects hippocampal neurons from amyloid beta-peptide induced cell death (Niidome, et al., 2007 and Khaengkhan, et al., 2009). The amyloid plaques are formed by the proteolysis of amyloid precursor protein by the by a, $B$ or $\mathrm{d}$ secretase enzyme. Therapeutic efforts to target $\mathrm{AD}$ have now focused on the disruption of this cascade by blocking these enzymes. Many flavones are identified from $M$. ihou with $B$-secretase inhibitory activity (Cho, et al., 2011). Cholinesterases are key enzymes that play important roles in cholinergic transmission. Eight flavonoids including kuwanon $\mathrm{U}$, kuwanon E, kuwanon C morusin, morusinol displaying cholinesterase inhibitory (both acetylcholine and butyrylcholine esterase) activity were isolated from the root bark of M. lhou L. (Kim, et al., 2011). The neuroprotective effect of oxyresveratrol was studied in in vitro model of stretch-induced trauma in co-cultures of neurons and glia, or by exposing cultures to high levels of glutamate. Trauma produced marked neuronal death and oxyresveratrol significantly inhibited this death. Microscopic examination of glia suggested signs of toxicity in cultures treated with $100 \mu \mathrm{M}$ oxyresveratrol, as demonstrated by elevated S-100B protein release and a high proportion of cells with condensed nuclei. Cultures exposed to glutamate for $24 \mathrm{~h}$ exhibited $~ 37 \%$ neuronal loss, which was not inhibited by oxyresveratrol (Weber, et al., 2012). Studies have demonstrated the beneficial effects of mulberry on the induction of an antioxidant defense system and improvement of memory deterioration in ageing animals (Shih, et al., 2010). The neuroprotective effect of cyanidine- 3-glucoside (C3G) fraction from $M$. alba was studied in oxygen deprivation and glutamate induced cell death in rat primary cortical neurons. C3G did not provide 
a protective effect against glutamate induced cell death, but provide protection against oxygen deprived cell death by maintaining the mitochondrial membrane potential (Bhuiyan, et al., 2011) (Fig. 6).

\section{The mulberry, Morus alba (L.) for skin diseases}

Melanin is a broad term for a group of natural pigments found in most organisms. Melanin is produced by the oxidation of the amino acid tyrosine, followed by polymerization. The melanin pigments are produced in a specialized group of cells known as melanocytes. There are three basic types of melanin: eumelanin, pheomelanin, and neuromelanin. The most common type is eumelanin, of which there are two typesbrown eumelanin and black eumelanin. Pheomelanin is a cysteine-derivative that contains polybenzothiazine portions that are largely responsible for the color of red hair, among other pigmentation. Neuromelanin is found in the brain, though its function remains obscure. In the human skin, melanogenesis is initiated by exposure to UV radiation, causing the skin to darken. Melanin is an effective absorbent of light; the pigment is able to dissipate over $99.9 \%$ of absorbed UV radiation. Because of this property, melanin is thought to protect skin cells from UVB radiation damage, reducing the risk of cancer, and it is considered that exposure to UV radiation is associated with increased risk of malignant melanoma, a cancer of melanocytes (melanin cells). Studies have shown a lower incidence for skin cancer in individuals with more concentrated melanin, i.e. darker skin tone. However; the relationship between skin pigmentation and photoprotection is still being investigated.

Melanin present in the skin protects from UV induced hyper pigmentation, wrinkling, melasma and cancer. Tyrosinase is an important enzyme in melanin production and in mammals the skin pigmentation results from the transfer of melanosomes from melanocytes to keratinocytes in the epidermis. $M$. alba L. leaf extract exhibited potent inhibitory effects on mushroom tyrosinase, mammalian tyrosinase, and melanin synthesis in Melan-a cells (Lee, et al., 2002). 2, 4, 2', 4'-Tetrahydroxy-3-(3-methyl-2-butenyl)chalcone (TMBC), obtained from the stem bark of mulberry, Morus nigra (L.) modulated melanogenesis by inhibiting tyrosinase. It inhibited the L-dopa oxidase activity of mushroom tyrosinase which was more potent than kojic acid a well-known tyrosinase inhibitor (Zhang, et al., 2009). Topical applications of mulberroside A, oxyresveratrol, and oxyresveratrol-3-Oglucoside clearly caused depigmentation, reduced melanin indices, inhibited tyrosinase activity, and decreased melanin content in UV induced hyperpigmentation in guinea pig skin. Oxyresveratrol and oxyresveratrol-3-Oglucoside more potently inhibited melanogenesis than mulberroside A. This treatment decreased the expression of MITF gene, that are regulating the transcription of proteins involved in melanocyte pigmentation (Park, et al., 2011). Mulberries also boast a high level of vitamin $\mathrm{A}$ and vitamin $\mathrm{E}$, along with a range of carotenoid components like lutein, beta-carotene, zeaxanthin, and alphacarotene. All of these elements act as antioxidants that specifically affect the skin, tissue, hair, and other areas of the body where free radicals strike. Mulberries can aid in skin care, reduce the appearance of blemishes and age spots, and keep hair shiny and healthy by preventing the oxidative actions of free radicals (Fig. 7).

\section{Hepatoprotective potentials of mulberry, Morus alba (L.)}

The chemical investigation of the twigs of $M$. mesozygia resulted in the isolation of several 
compounds and few of them exhibited heaptoprotective activities (Kapche, et al., 2011). A glycoprotein (MIL) purified from $M$. indica protects againt $\mathrm{CCl} 4$ induced liver damage. MIL significantly reduced the activity of alanine aminotransferase (ALT), lactate dehydrogenase (LDH), and thiobarbituric acid-reactive substances (TBARS) in $\mathrm{CCl} 4$ treated mice. It reduced the activity of COX-2 and expression of TNF-a and IL-1 beta in liver from CCl4- treated mice. Moreover, supplementation of MIL suppressed stress-activated protein kinase/cjun $\mathrm{N}$-terminal kinase phosphorylation and activator protein-1 transcriptional activation in livers of $\mathrm{CCl} 4$ treated mice $(\mathrm{Oh}$, et al., 2010). M. alba extract significantly reduced the gastric mucosal injury in experimental rats induced by tween 20 and absolute ethanol with marked reduction in the leucocytes infiltration to submucosal layer (Abdulla, et al., 2009) (Fig. 8).

\section{The mulberry, Morus alba (L.) for gastrointestinal disorders}

The health benefits of mulberries include their ability to improve digestion, lower cholesterol, aid in weight loss, increase circulation, build bone tissues, and boost the immune system. The fruit also helps prevent certain cancers, slow down the aging process, lower blood pressure, protect eyes, and improve the overall metabolism of the body. Mulberries are filled with nutrients that are important for our body, including iron, riboflavin, vitamin $\mathrm{C}$, vitamin $\mathrm{K}$, potassium, phosphorous, and calcium. They also contain a significant amount of dietary fiber and a wide range of organic compounds, including phytonutrients, zeaxanthin, resveratrol, anthocyanins, lutein, and various polyphenolic compounds. Like the majority of fruits and vegetables, mulberries contain dietary fiber, which makes approximately $10 \%$ of your daily requirements in a single serving. Dietary fiber can help to improve digestion by bulking up the stool, thereby speeding up the movement of food through the digestive tract, while also reducing occurrences of constipation, bloating, and cramping. Furthermore, fiber helps to regulate cholesterol levels and can improve heart health when regularly added to the diet. Like the majority of fruits and vegetables, mulberries contain dietary fiber, which makes approximately $10 \%$ of your daily requirements in a single serving. Dietary fiber can help to improve digestion by bulking up the stool, thereby speeding up the movement of food through the digestive tract, while also reducing occurrences of constipation, bloating, and cramping. Furthermore, fiber helps to regulate cholesterol levels and can improve heart health when regularly added to the diet.

Exploring and evaluating new and cheap feedstuffs as sources of protein for livestock and other farm animals is an important target for nutritionists to pursue. Competition between man and animal for the same food and the search for alternatives to feed livestock are increasing. The increasing costs of conventional feedstuffs like corn, soybean meal and fish meal for poultry diets is pushing to find less expensive alternatives. One possible feed alternative is tree fodder mulberry leaves (Morus alba). Mulberry grows well in the tropics and subtropics, and is reported to have excellent nutritional value. Mulberry leaves are very rich in protein (15$35 \%)$, minerals $[2.42-4.71 \%$ calcium $(\mathrm{Ca})$; $0.23-0.97 \%$ phosphorus (P)] and metabolizable energy (1130- $2240 \mathrm{kcal} / \mathrm{kg})$ with absence of or negligible anti-nutritional factors (Omar et al., 1999; Sanchez, 2002; Saddul et al., 2004; Sarita et al., 2006; Wang et al., 2011). The amino acids composition of mulberry leaf meal indicates it is a good source of essential amino acids especially lysine $1.80 \%$ and leucine $2.58 \%$ (Al-Kirshi et 
al., 2009). Excellent results have been obtained with mulberry leaves as poultry feed (Chowdary et al., 2009; Al-Kirshi et al., 2010; Olteanu et al., 2010).

\section{Antimicrobial effects of mulberry, Morus alba (L.)}

The methanolic extract of the bark of $M$. mesozygia as well as its constituents (cycloartocarpesin and different types of moracins) are used for the treatment of infections associated with microorganisms (Kuete, et al., 2009). Prenylated flavonoids isolated from $M$. alba showed antibacterial, antifungal and antiviral activities (Du, et al., 2003 and Sohn et al., 2004). Kuwanon G was isolated from the ethyl acetate fraction of methanol extract of $M$. alba is acting as an antibacterial agent against oral pathogens (Park et al., 2003). Chalcomoracin, a leaf phytoalexine of mulberry tree exhibited considerable antibacterial activity against methicillin-resistant Stapalococcus aureus (Fukai et al., 2005). Alisson Macário de Oliveira et al., (2015) evaluated an ethanolic extractives of leaves of mulberry, Morus alba (L.) for toxicity to Artemia salina (L.), oral toxicity to mice, and antimicrobial activity. Phytochemical analysis revealed the presence of coumarins, flavonoids, tannins, and triterpenes in the extract, which did not show toxicity to A. salina nauplii. No mortality and behavioral alterations were detected for mice treated with the extract (300 and $2000 \mathrm{mg} / \mathrm{kg}$ b.w.) for 14 days. However, animals that received the highest dose showed reduced MCV and MCHC as well as increased serum alkaline phosphatase activity. In treatments with the extract at both 300 and $2000 \mathrm{mg} / \mathrm{kg}$, there was a reduction in number of leukocytes, with decrease in percentage of lymphocytes and increase in proportion of segmented cells. Histopathological analysis of organs from mice treated with the extract at $2000 \mathrm{mg} / \mathrm{kg}$ revealed turgidity of contorted tubules in kidneys, presence of leukocyte infiltration around the liver centrilobular vein, and high dispersion of the spleen white pulp. The extract showed antimicrobial activity against Staphylococcus aureus, Pseudomonas aeruginosa, Candida albicans, Candida krusei, Candida tropicalis and Aspergillus flavus. In conclusion, the extract contains antimicrobial agents and was not lethal for mice when ingested; however, its use requires caution because it promoted biochemical, hematological, and histopathological alterations.

Fig.1 Mulberry, the safe therapeutics for human health

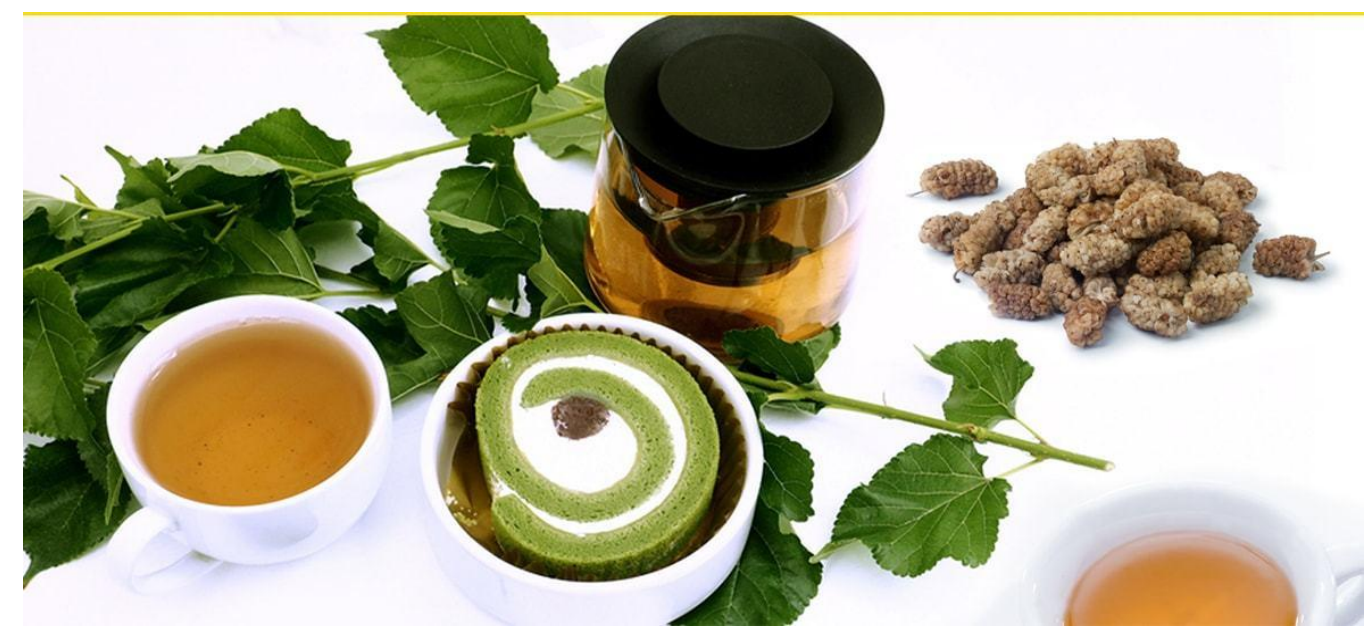


Fig.2 Herbal mulberry tea for keeping the diabetes away
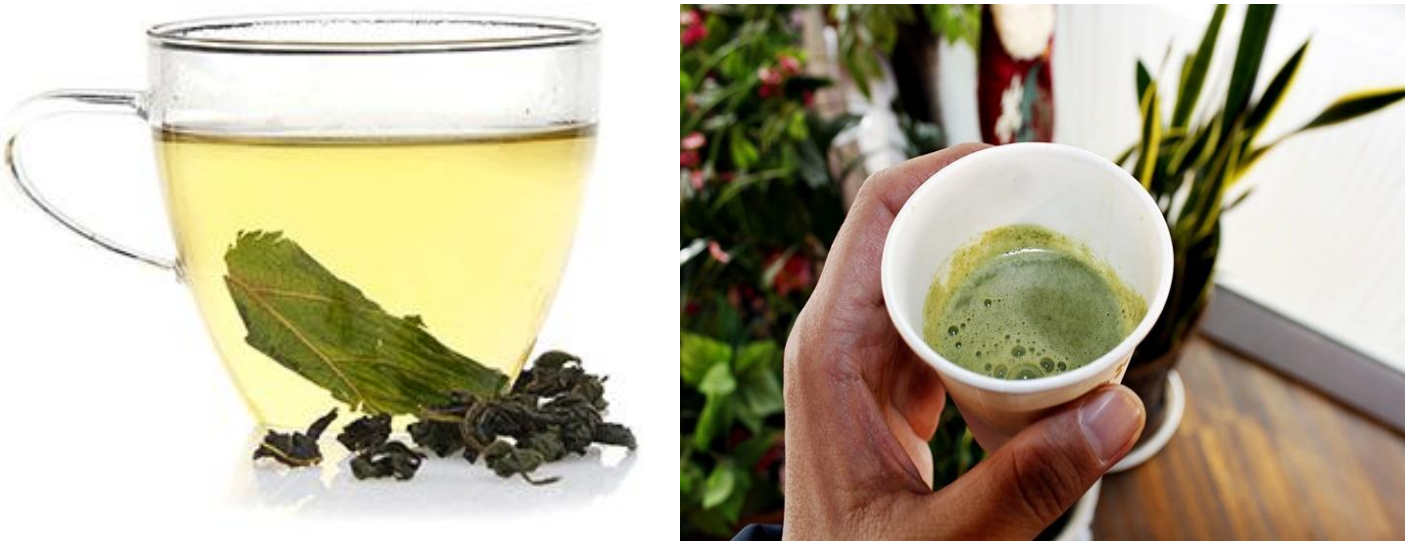

Fig.3 The contents of mulberry, Morus alba (L.) serve to orchestrate the progression of Healthy heart
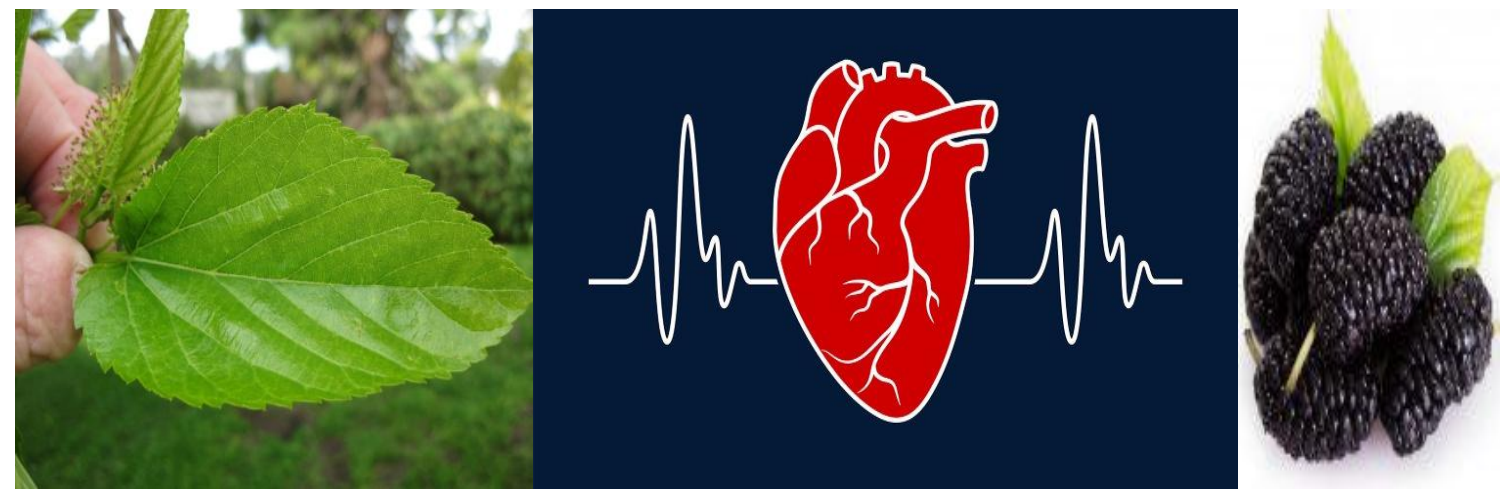

Fig.4 The cancer preventing bioactive compounds from Herbal Sources

Bioactive compounds from different sources have shown anti-cancer activity by directly targeting cancer stem cells.

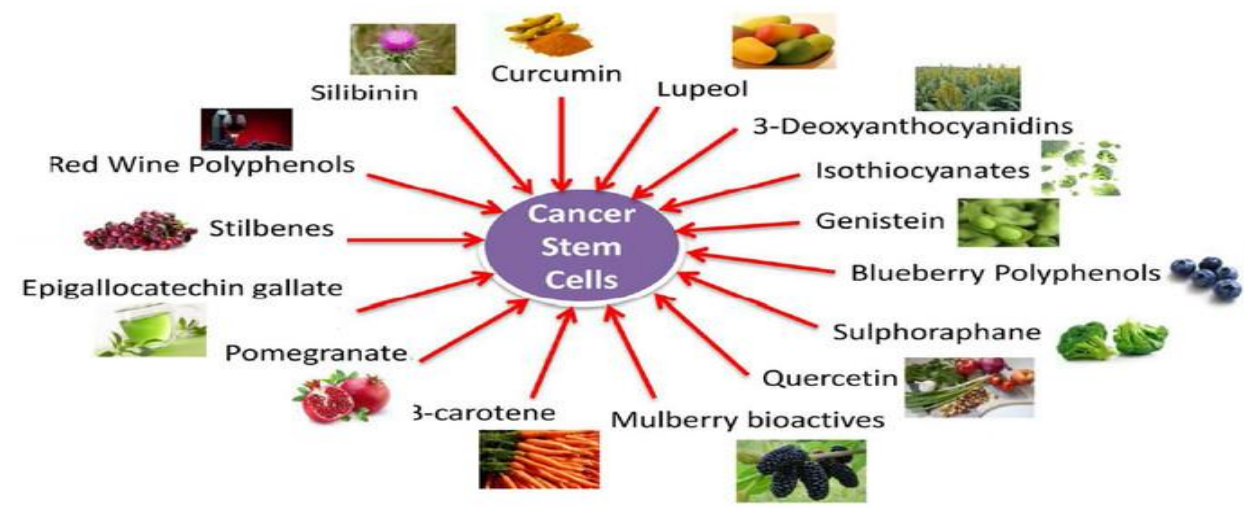


Fig.5 The mechanism of inflammation

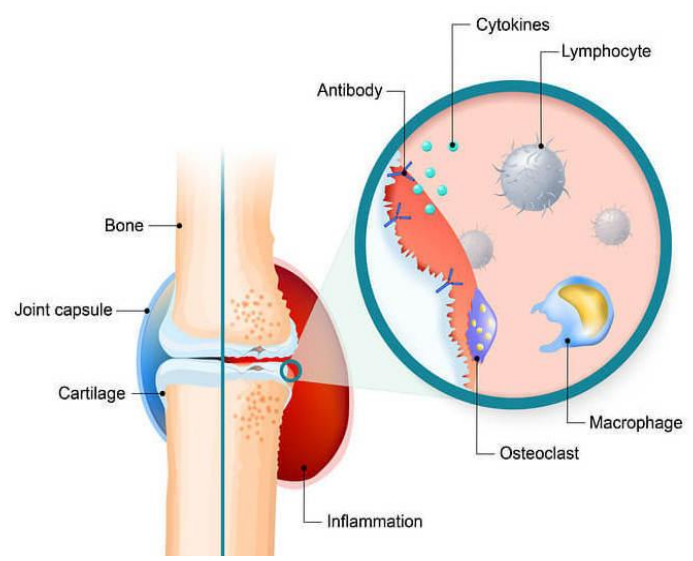

Fig.6 The neurological disorders

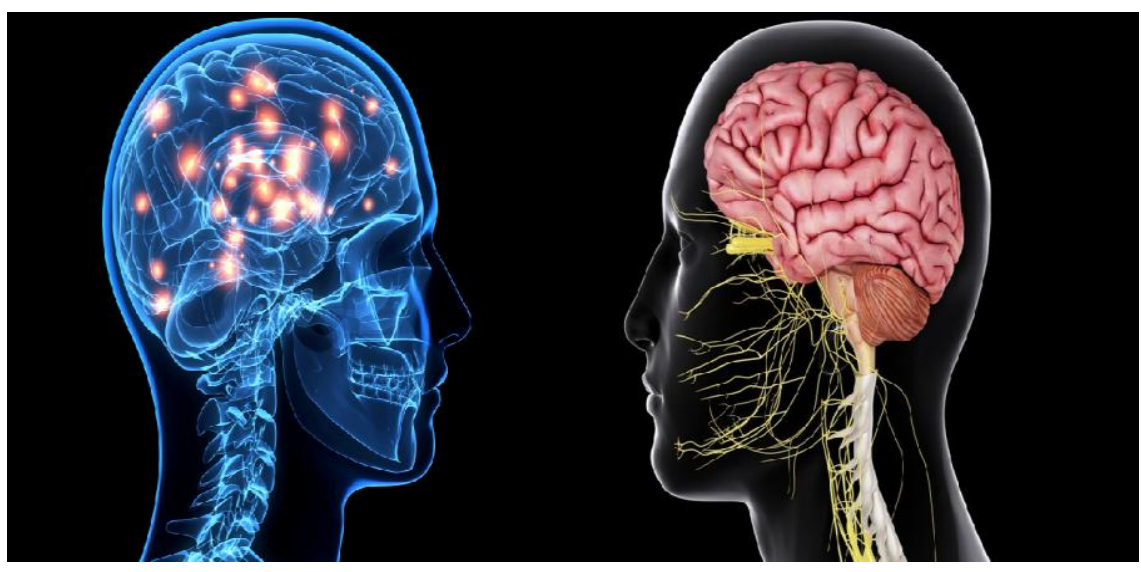

Fig.7 Mulberry, Morus alba (L.) for skin diseases

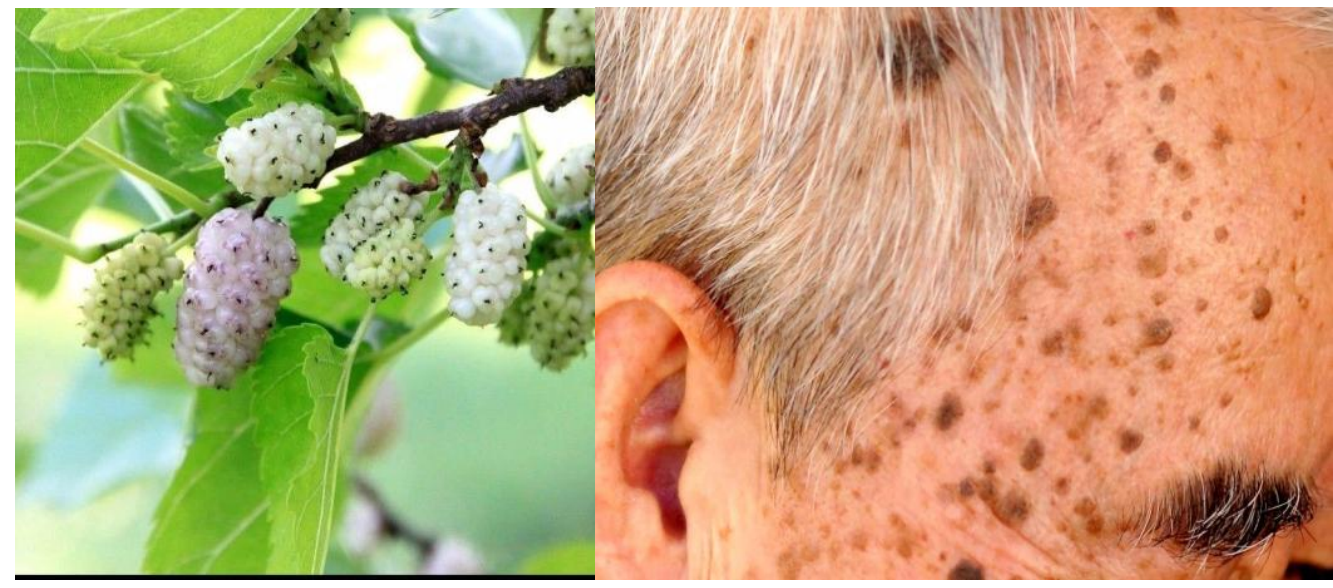


Fig.8 Mulberry, Morus alba (L.) for liver protection
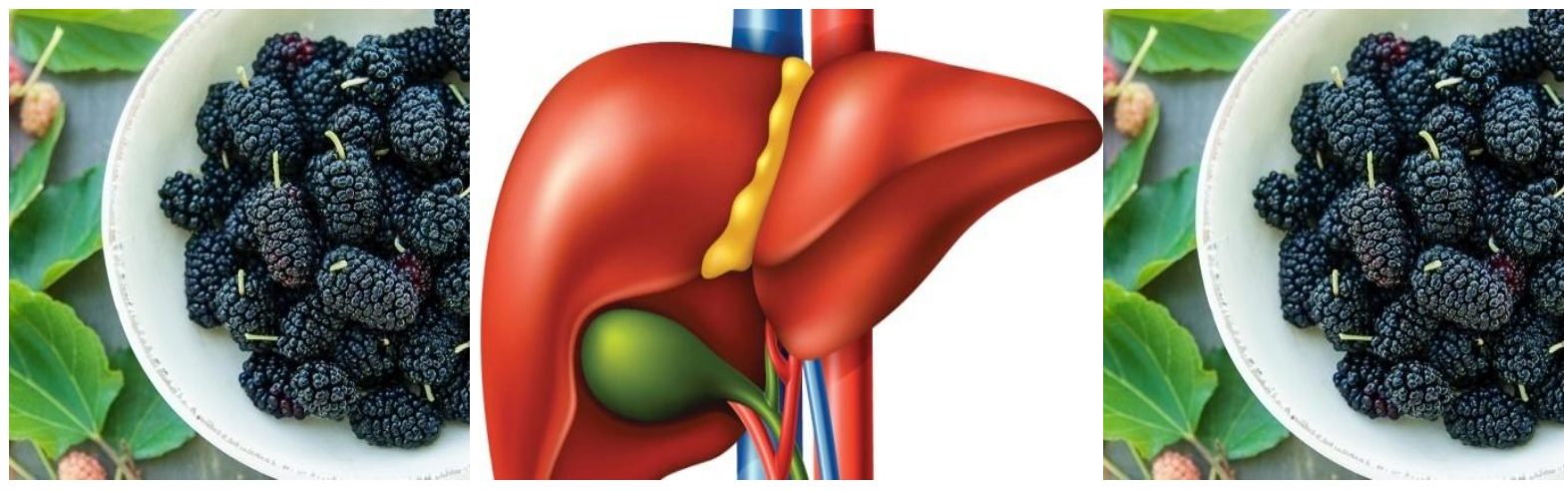

Fig.9 Mulberry: The ancient super food of silkworms and now, for human being

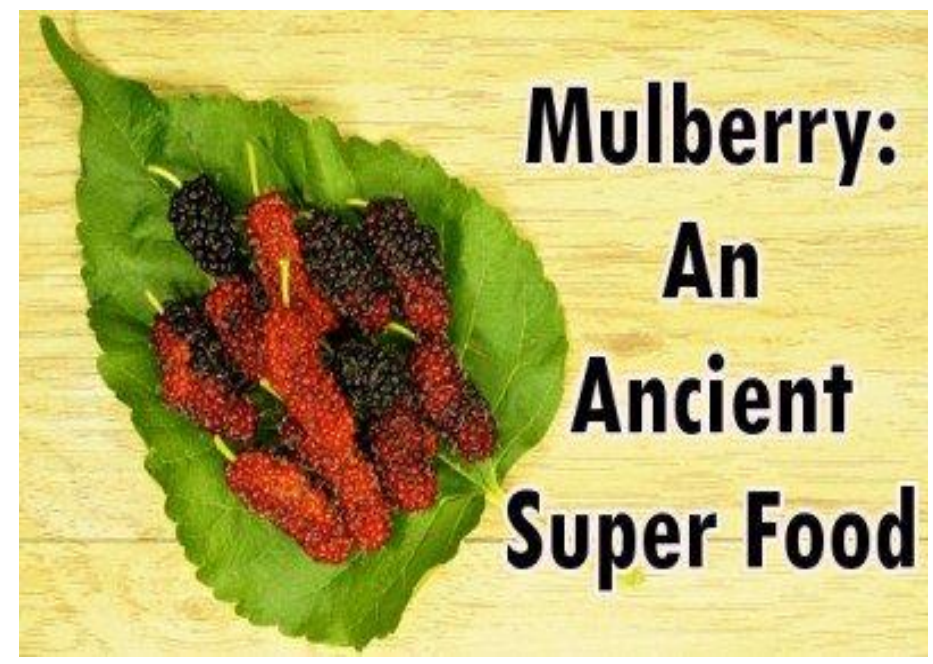

In conclusion, the mulberry is the one among the most studied plants for pharmacological potential. Research over the years elucidated the existence of a number of active molecules in it. The mechanism included in the exciting pharmacological effect has been studied with a significant number of compounds purified from mulberry. The synthetic analogues of the purified compounds are showed to be effective in the treatment of various diseases. More detailed studies in future with the natural vs. synthetic compounds will clearly show the potential of these compounds in the therapeutic field.
It is expected that in the 21 st century more research will be focused on the natural source based compounds to treat various diseases and mulberry is definitely be one of the species to be explored more extensively. One of the carotenoids found in mulberries is zeaxanthin, which has been connected directly to a reduction in oxidative stress on certain ocular cells, including the retinal macula lutea. Furthermore, zeaxanthin functions as an antioxidant and prevents certain damage to the retina, including the free radicals that can cause macular degeneration and cataracts. Vitamin $\mathrm{C}$ is a 
powerful defensive weapon against any illness or foreign pathogens in the body that antioxidants don't take care of. A single serving of mulberries is almost the entire requirement of vitamin $\mathrm{C}$ for the day, but combine that with the minerals and vitamins present in this fruit, and you have a true weapon against illness. Add a few mulberries to your morning meal and watch your immune system soar.

\section{Acknowledgement}

Expertise support from Mulberry Garden of Sericulture Unit, Malegaon Sheti Farm, Agricultural Development Trust, Baramati (India) deserve appreciations and exert a grand salutary influence.

\section{References}

Scrivastava S, Kapoor R, Thratola A, Scrivastava RP. Mulberry (Morus alba) leaves as human food: a new dimension in sericulture. Int $J$ Food Sci Nutr 2003; 338: 3-10.

Andallu B, Varadacharyulu NC. Antioxidant role of mulberry (Morus indica L. cv. Anantha) leaves in streptozotocin-diabetic rats. Clin Chim Acta 2003; 338: 3-10.

Asano N, Yamashita T, Yasuda K, IkedaK, Kizu H, Kameda Y, Kato A, Nash RJ, Lee HS, Ryu KS. Polyhydroxylated alkaloids isolated from mulberry trees (Morus alba L.) and silkworms (Bombix mori L.). J Agric Food Chem 2001; 49: 4208-13.

Harauma A, Murayama T, Ikeyama K, Sano H, Arai H, Takano R, Kita T, Hara S, Kamei K, Yokode M. Mulberry leaf powder prevents atherosclerosis in apolipoprotein E-deficient mice. Biochem Biophys Res Commun 2007; 358: 751-6.

Arfan M, Khan R, Rybarczyk A, Amarowicz R. Antioxidant Activity of Mulberry Fruit Extracts. Int J Mol Sci 2012; 13: 2472-80.

Chu Q, Lin M, Tian X, Ye J. Study on capillary electrophoresis amperometric detection profiles of different parts of Morus alba L. $J$ Chromatogr A 2006; 1116: 286-90.

Chang LW, Juang LJ, Wang BS, Wang MY, Tai HM, Hung WJ, Chen YJ, Huang MH.
Antioxidant and antityrosinase activity of mulberry (Morus alba L.) twigs and root bark. Food Chem Toxicol 2011; 49: 785-90.

Ercisli S, Orhan E. Chemical composition of white (Morus alba), red (Morus rubra) and black (Morus nigra) mulberry fruits. Food Chem 2007; 103: 1380-4.

Ni G, Zhang QJ, Wang HY, Chen RY, Zheng FZ, $\mathrm{Yu}$ DQ Chemical constituents of the stem bark of Morus cathayana. J Asian Nat Prod Res 2010; 12: 505-15.

Tan XY, Gong T, Liu C, Chen RY, Yu DQ. Five New 2- Arylbenzofuran Derivatives from Morus wittiorum. Chem. Pharm.Bull. 2010; 58: 579-81.

Piao SJ, Chen LX, Kang N, Qiu F. Simultaneous determination of five characteristic stilbene glycosides in root bark of Morus alba L. (Cortex Mori) using high-performance liquid chromatography. Phytochem Anal 2011; 22: 230-5.

Zheng ZF, Zhang QJ, Chen RY, Yu DQ. Four new flavonoids from Morus australis. J Asian Nat Prod Res 2012;14: 263-9.

Kim GN, Jang HD. Flavonol content in the water extract of the mulberry (Morus L.)?alba leaf and their antioxidant capacities. J Food Sci 2011; 76: C869-73.

Ali A, Ali M. New triterpenoids from Morus alba L. stem bark. Nat Prod Res. 2012 Apr 5. [Epub ahead of print].

Kim ES, Park SJ, Lee EJ, Kim BK, Huh H, Lee BJ. Purification and characterization of Moran 20K from Morus alba. Arch Pharm Res 1999; 22: 9-12.

Song W, Wang HJ, Bucheli P, Zhang PF, Wei DZ, $\mathrm{Lu}$ YH. Phytochemical profiles of different mulberry (Morus sp.) species from China. $J$ Agric Food Chem 2009; 57: 9133-40.

Wu D, Zhang X, Huang X, He X, Wang G, Ye W. Chemical constituents from root barks of Morus atropurpurea. Zhongguo Zhong Yao Za Zhi 2010; 35: 1978-82.

Kumar VR, Chauhan S. Mulberry: Life enhancer. $J$ Med Plants Res 2008; 2: 271-8.

Butt MS, Nazir A, Sultan MT, Schroen K. Morus alba L. nature's functional tonic. Trends Food Sci Tech 2008; 19: 505-12.

Ahmed N. Advanced glycation end products-role in pathology of diabetic complications. Diabetes Res Clin Pract 2005; 67: 3-21.

Baynes JW, Thorpe SR. Glycoxidation and lipoxidation in atherogenesis. Free Radic Biol 
Med 2000; 28: 1708-16.

Naowaboot J, Pannangpetch P, Kukongviriyapan V, Kongyingyoes B, Kukongviriyapan U. Antihyperglycemic, antioxidant and antiglycation activities of mulberry leaf extract in streptozotocin induced chronic diabetic rats. Plant Foods Hum Nutr 2009; 64: 116-21.

Jang MH, Kim H, Shin MC, Lim BV, Lee TH, Jung $\mathrm{SB}$, Kim CJ, Kim EH. Administration of Folium mori extract decreases nitric oxide synthase expression in the hypothalamus of streptozotocin induced diabetic rats. Jpn J Pharmacol 2002; 90: 189-92.

Sharma SB, Gupta S, Ac R, Singh UR, Rajpoot R, Shukla SK. Antidiabetogenic action of Morus rubra L. leaf extract in streptozotocin-induced diabetic rats. J Pharm Pharmacol 2010; 62: 247-55.

Hansawasdi C, Kawabata J. Alpha-glucosidase inhibitory effect of mulberry (Morus alba) leaves on Caco-2. Fitoterapia 2006; 77: 56873.

Li YG, Ji DF, Zhong S, Lv ZQ, Lin TB, Chen S, Hu GY. Hybrid of 1-deoxynojirimycin and polysaccharide from mulberry leaves treat diabetes mellitus by activating PDX1/insulin-1 signaling pathway and regulating the expression of glucokinase, phosphoenolpyruvate carboxykinase and glucose-6-phosphatase in alloxaninduced diabetic mice. J Ethnopharmacol 2011; 134: 961-70.

Taniguchi S, Asano N, Tomino F, Miwa I. Potentiation of glucose induced insulin secretion by fagomine, a pseudosugar isolated from mulberry leaves. Horm Metab Res 1998; 30: 679-83.

Andallu B, Suryakantham V, Lakshmi Srikanthi B, Reddy GK. Effect of mulberry (Morus indica L.) therapy on plasma and erythrocyte membrane lipids in patients with type 2 diabetes. Clin Chim Acta 2001; 314: 47-53.

Zhang M, Chen M, Zhang HQ, Sun S, Xia B, Wu FH. In vivo hypoglycemic effects of phenolics from the root bark of Morus alba. Fitotherapia 2009a; 80: 475-7.

Sudha P, Zinjarde SS, Bhargava SY, Kumar AR. Potent a-amylase inhibitory activity of Indian Ayurvedic medicinal plants. BMC Compl Alt Med 2011; 11: 5-15.

Haffner SM. Compositional changes in lipoproteins of subjects with non-insulin-dependent diabetes mellitus. J Lab Clin Med 1991; 118: 109-10.

Tanabe K, Nakamura S, Omagari K, Oku T. Repeated ingestion of the leaf extract from Morus alba reduces insulin resistance in KKAy mice. Nutr Res 2011; 31: 848-54.

Kim HJ, Yoon KH, Kang MJ, Yim HW, Lee KS, Vuksan V, Sung MK. A six-month supplementation of mulberry, korean red ginseng, and banaba decreases biomarkers of systemic low-grade inflammation in subjects with impaired glucose tolerance and type 2 diabetes. Evid Based Complement Alternat Med 2012 Feb 28 [Epub ahead of print].

Musi N, Goodyear LJ. Insulin resistance and improvements in signal transduction. Endocrine 2006; 29: 73-80.

Ma X, Iwanaka N, Masuda S, Karaike K, Egawa T, Hamada T, Toyoda T, Miyamoto L, Nakao K, Hayashi T. Morus alba leaf extract stimulates 5'-AMP-activated protein kinase in isolated rat skeletal muscle. J Ethnopharmacol 2009; 122: 54-9.

Nadler ST, Stoehr JP, Schueler KL, Tanimoto G, Yandell BS, Attie AD. The expression of adipogenic genes is decreased in obesity and diabetes mellitus. Proc Natl Acad Sci U S A 2000; 97: 11371-6.

Naowaboot J, Chung CH, Pannangpetch P, Choi R, Kim BH, Lee MY, Kukongviriyappan U. Mulberry leaf extract increases adiponectin in murine 3T3-L1 adipocytes. Nutr Res 2012; 32: 39-44.

Oh KS, Han W, Wang MH, Lee BH. The effects of chronic treatment with Morus bombycis KOIDZUMI in spontaneously hypertensive rats. Biol Pharm Bull 2007; 30: 1278-83.

Doi, K., Kojima, T., Fujimoto, Y. Mulberry leaf extract inhibits the oxidative modification of rabbit and human low density lipoprotein. Biol Pharm Bull 2000; 23: 1066-71.

Xia M, Qian L, Zhou X, Gao Q, Bruce IC, Xia Q. Endothelium independent relaxation and contraction of rat aorta induced by ethyl acetate extract from leaves of Morus alba (L.). J Ethnopharmacol 2008; 120: 442-6.

Kobayashi Y, Miyazawa M, Kamei A, Abe K, Kojima T. Ameliorative effects of Mulberry (Morus alba L.) leaves on hyperlipidemia in rats fed a high fat diet: induction of fatty acid oxidation, inhibition of lipogenesis and suppression of oxidative stress. Biosci Biotechnol Biochem 2010; 74: 2385-95. 
Kim YS, Lee YM, Kim H, Kim J, Jang DS, Kim JH, Kim JS. Antiobesity effect of Morus bombycis root extract: anti-lipase activity and lipolytic effect. J Ethnopharmacol 2010; 130: 621-4.

Tsuduki T, Nakamura Y, Honma T, Nakagawa K, Kimura T, Ikeda I, Miyazawa T. Intake of 1deoxynojirimycin suppresses lipid accumulation through activation of the $B$ oxidation system in rat liver. J Agric Food Chem 2009; 57: 11024-29.

Ou TT, Hsu MJ, Chan KC, Huang CN, Ho HH, Wang CJ. Mulberry extract inhibits oleic acid-induced lipid accumulation via reduction of lipogenesis and promotion of hepatic lipid clearance. J Sci Food Agric 2011; 91: 2740-8.

Kojima Y, Kimura T, Nakagawa K, Asai A, Hasumi $\mathrm{K}$, Oikawa S, Miyazawa T. Effects of mulberry leaf extract rich in 1deoxynojirimycin on blood lipid profiles in humans. J Clin Biochem Nutr 2010; 47: 15561.

Yang X, Yang L, Zheng H. Hypolipidemic and antioxidant effects of mulberry (Morus alba L.) fruit in hyperlipidaemia rats. Food Chem Toxicol 2010a; 48: 2374-9.

Arumugam S, Thandavarayan RA, Veeraveedu PT, Ma M, Giridharan VV, Arozal W, Sari FR, Sukumaran V, Lakshmanan A, Soetikno V, Suzuki K, Kodama M, Watanabe K. Modulation of endoplasmic reticulum stress and cardiomyocyte apoptosis by mulberry leaf diet in experimental autoimmune myocarditis rats. J Clin Biochem Nutr 2012; 50: $139-44$.

Lee JJ, Yang H, Yoo YM, Hong SS, Lee D, Lee HJ, Lee HJ, Myung CS, Choi KC, Jeung EB. Morusinol Extracted from Morus alba Inhibits Arterial Thrombosis and Modulates Platelet Activation for the Treatment of Cardiovascular Disease. $J$ Atheroscler Thromb 2012 Apr 4. [Epub ahead of print].

Hu X, Ji J, Wang M, Wu JW, Zhao QS, Wang HY, Hou AJ. New isoprenylated flavonoids and adipogenesis-promoting constituents from Morus notabilis. Bioorg Med Chem Lett 2011b; 21: 4441- 6 .

Hu X, Wu JW, Zhang XD, Zhao QS, Huang JM, Wang HY, Hou AJ. Isoprenylated flavonoids and adipogenesis-promoting constituents from Morus nigra. J Nat Prod 2011a; 74: 816-24.

Chan KC, Ho HH, Huang CN, Lin MC, Chen HM,
Wang CJ. Mulberry leaf extract inhibits vascular smooth muscle cell migration involving a block of small GTPase and Akt/NF-kappaB signals. J Agric Food Chem 2009; 57: 9147-53.

Chan KC, Ho HH, Peng CH, Lan KP, Lin MC, Chen HM, Wang CJ. Polyphenol-rich extract from mulberry leaf inhibits vascular smooth muscle cell proliferation involving upregulation of p53 and inhibition of cyclin-dependent kinase. J Agric Food Chem 2010; 58: 253642.

Jeong JC, Jang SW, Kim TH, Kwon CH, Kim YK. Mulberry fruit (Moris fructus) extracts induce human glioma cell death in vitro through ROS-dependent mitochondrial pathway and inhibits glioma tumor growth in vivo. Nutr cancer 2010; 62: 402-12.

Naowaratwattana W, De-Eknamkul W, De Mejia EG. Phenoliccontaining organic extracts of mulberry (Morus alba L.) leaves inhibit HepG2 hepatoma cells through G2/M phase arrest, induction of apoptosis, and inhibition of topoisomerase IIa activity. J Med Food 2010; 13:1045-56.

Kikuchi T, Nihei M, Nagai H, Fukushi H, Tabata K, Suzuki T, Akihisa T. Albanol A from the root bark of Morus alba L. induces apoptotic cell death in HL60 human leukemia cell line. Chem Pharm Bull 2010; 58: 568-71.

Patharakorn T, Arpornsuwan T, Wetprasit N, Promboon A, Ratanapo S. Antibacterial activity and cytotoxicity of the leaf essential oil of Morus rotunbiloba Koidz. J Med Plants Res 2010; 4; 837-43.

Ahn SC, Kim BY, Oh WK, Park YM, Kim HM, Ahn JS. Colorimetric heparinase assay for alternative anti-metastatic activity. Life Sci 2006; 79: 1661-5.

Dat NT, Binh PT, Quynl le TP, Minh CV, Huong HT, Lee JJ. Cytotoxic prenylated flavonoids from Morus alba. Fitoterapia 2010; 81: 12247.

Yang Y, Gong T, Liu C, and Chen RY Four New 2Arylbenzofuran Derivatives from Leaves of Morus alba L. Chem Pharm Bull 2010; 58: 257-60.

Tan YX, Wang HQ, Chen RY. Anti-inflammatory and cytotoxic 2- arylbenzofurans from Morus wittiorum. Fitotherapia 2012 Mar 10 [Epub ahead of print].

Deepa $M$ and Priya S. Purification and characterization of a novel anti-proliferative 
lectin from Morus alba L. Leaves. Prot Pept Lett 2012.

Middleton Jr. E, Kandaswami C, Theoharides TC. The effects of plant flavonoids on mammalian cells: implications for inflammation, heart disease, and cancer. Pharmacol Rev 2000; 52: 673-751.

Chen PN, Chu SC, Chiou HL, Kuo WH, Chiang CL, Hsieh YS. Mulberry anthocyanins, cyanidin 3-rutinoside and cyanidin 3- glucoside, exhibited an inhibitory effect on the migration and invasion of a human lung cancer cell line. Cancer Lett 2006; 235: 248- 59.

Huang TT, Liu FG, Wei CF, Lu CC, Chen CC, Lin $\mathrm{HC}$, Ojcius DM, Lai HC. Activation of multiple apoptotic pathways in human nasopharyngeal carcinoma cells by the prenylated isoflavone, osajin. PLoS One 2011; 6: e18308.

Yang Y, Zhang T, Xiao L, Yang L, Chen R. Two new chalcones from leaves of Morus alba $\mathrm{L}$. Fitotherapia 2010; 81: 614-6.

Shi YQ, Fukai T, Sakagami H, Chang WJ, Yang PQ, Wang FP, Nomura T. Cytotoxic flavonoids with isoprenoid groups from Morus mongolica. J Nat Med 2001; 64: 181-8.

Wang R, Lu XC, Wang YW. Antiinflammatory activity of the extracts of Ramulus mori. $J$ Wuhan Bot Res 2002; 20: 467-9.

Choi EM, Hwang JK. Effects of Morus alba leaf extract on the production of nitric oxide, prostaglandin E2 and cytokines in RAW264.7 macrophages. Fitoterapia 2005; 76: 608-13.

Hong CH, Hur SK, Oh OJ, Kim SS, Nam KA, Lee SK. Evaluation of natural products on inhibition of inducible cyclooxygenase (COX-2) and nitric oxide synthase (iNOS) in cultured mouse macrophage cells. $J$ Ethnopharmacol 2002; 83: 153-9.

Kim HJ, Lee HJ, Jeong SJ, Lee HJ, Kim SH, Park EJ. Cortex Mori Radicis extract exerts antiasthmatic effects via enhancement of CD4(+)CD25(+)Foxp3(+) regulatory $\mathrm{T}$ cells and inhibition of Th2 cytokines in a mouse asthma model. J Ethnopharmacol 2011a; 138: 40-6.

Kim HS, Kim AR, Park HJ, Park DK, Kim do K, Ko NY, Kim B, Choi DK, Won HS, Shin WS, Kim YM, Choi WS. Morus bombycis Koidzumi extract suppresses collageninduced arthritis by inhibiting the activation of nuclear factor-? B and activator protein-1 in mice. J Ethnopharmacol 2011b; 136: 392-
8.

Kim AJ, Park S. Mulberry extract supplements ameliorate the inflammation-related hematological parameters in carrageenaninduced arthritic rats. J Med Food 2006; 9: 431-5.

Padilha MM, Vilela FC, Rocha CQ, Dias MJ, Soncini R, dos Santos MH, Alves-da-Silva G, Giusti-Paiva A. Antiinflammatory properties of Morus nigra leaves. Phytother Res 2010; 24: 1496- 500.

Hošek J, Bartos M, Chudik S, DallAcua S, Innocenti G, Kartal M, Kokoska L, Kollar P, Kutil Z, Landa P, Marek R, Zavalova V, Zemlicka M, Smejkal K. Natural compound cudraflavone B shows promising anti-inflammatory properties in vitro. J Nat Prod 2011; 74: 6149.

Oh YC, Kang OH, Choi JG, Chae HS, Lee YS, Brice OO, Jung HJ, Hong SH, Lee YM, Kwon DY. Anti-inflammatory effect of resveratrol by inhibition of IL-8 production in LPS-induced THP- 1 cells. Am J Chin Med 2009; 37: 1203-14.

Dat NT, Binh PT, Quynl le TP, Huong HT, Minh CV. Sanggenon $\mathrm{C}$ and $\mathrm{O}$ inhibit NO production, iNOS expression and NF-?B activation in LPS-induced RAW264.7 cells. Immunopharmacol Immunotoxicol 2012; 34: 84-8.

Yang ZG, Matsuzaki K, Takamatsu S, Kitanaka S. Inhibitory effects of constituents from Morus alba var. multicaulis on differentiation of 3T3-L1 cells and nitric oxide production in RAW264.7 cells. Molecules 2011; 16: 601022.

Phung TX, Tran TH, Dan TT, Chau VM, Hoang TH, Nguyen TD. Chalcone-derived Diels-Alder adducts as NF-?B inhibitors from Morus alba. J Asian Nat Prod Res 2012; 14: 596-600.

Chen SK, Zhao P, Shao YX, Li Z, Zhang C, Liu P, $\mathrm{He} \mathrm{X}$, Luo HB, Hu X. Moracin M from Morus alba $\mathrm{L}$. is a natural phosphodiesterase4 inhibitor. Bioorg Med Chem Lett 2012; 22: $3261-4$

Niidome T, Takahashi K, Goto Y, Goh S, Tanaka N, Kamei K, Ichida M, Hara S, Akaike A, Kihara T, Sugimoto H. Mulberry leaf extract prevents amyloid beta-peptide fibril formation and neurotoxicity. Neuroreport. 2007 May 28;18(8):813-6.

Khaengkhan P, Nishikaze Y, Niidome T, Kanaori K, Tajima K, Ichida M, Harada S, Sugimoto H, 
Kamei K. Identification of an antiamyloidogenic substance from mulberry leaves. Neuroreport 2009; 20: 1214-8.

Cho JK, Ryu YB, Curtis-Long MJ, Kim JY, Kim D, Lee S, Lee WS, Park KH. Inhibition and structural reliability of prenylated flavones from the stem bark of Morus lhou on Bsecretase (BACE- 1). Bioorg Med Chem Lett 2011; 21: 2945-8.

Kim JY, Lee WS, Kim YS, Curtis-Long MJ, Lee BW, Ryu YB, Park KH. Isolation of cholinesterase-inhibiting flavonoids from Morus lhou. J Agric Food Chem 2011; 59: 4589-96.

Weber JT, Lamont M, Chibrikova L, Fekkes D, Vlug AS, Lorenz P, Kreutzmann P, Slemmer JE. Potential neuroprotective effects of oxyresveratrol against traumatic injury. Eur $J$ Pharmacol 2012; 680: 55-62.

Shih PH, Chan YC, Liao JW, Wang MF, Yen GC. Antioxidant and cognitive promotion effects of anthocyanin-rich mulberry (Morus atropurpurea L.) on senescence-accelerated mice and prevention of Alzheimer's disease. $J$ Nutr Biochem 2010; 21: 598-605.I

Bhuiyan MIH, Kim HB, Kim SY, Cho KO. The neuroprotective potential of cyanidin-3glucoside fraction extracted from mulberry following oxygen-glucose deprivation. Korean J Physiol Pharmacol 2011; 15: 35361.

Lee SH, Choi SY, Kim H, Hwang JS, Lee BG, Gao JJ, Kim SY. Mulberroside F isolated from the leaves of Morus alba inhibits melanin biosynthesis. Biol Pharm Bull 2002; 25: 1045-8.

Zhang X, Hu X, Hou A, Wang H. Inhibitory effect of 2,4,2',4'- tetrahydroxy-3-(3-methyl-2butenyl)-chalcone on tyrosinase activity and melanin biosynthesis. Biol Pharm Bull 2009b; 32: 86-90.

Park KT, Kim JK, Hwang D, Yoo Y, Lim YH. Inhibitory effect of mulberroside $\mathrm{A}$ and its derivatives on melanogenesis induced by ultraviolet B irradiation. Food Chem Toxicol 2011; 49: 3038-45.

Kapche GD, Amadou D, Waffo-Teguo P, Donfack $\mathrm{JH}$, Fozing CD, Harakat D, Tchana AN, Mérillon JM, Moundipa PF, Ngadjui BT, Abegaz BM. Hepatoprotective and antioxidant arylbenzofurans and flavonoids from the twigs of Morus mesozygia. Planta Med 2011; 77: 1044-7.
Oh PS, Lee J, Lim KT. Inhibitory effect of MIL glycoprotein on expression of proinflammatory mediators in carbon tetrachloride induced mice liver damage. $J$ Appl Toxicol 2010; 30: 754-60.

Abdulla MA, Ali HM, Ahmed KA, Noor SM, Ismail S. Evaluation of the anti-ulcer activities of Morus alba extracts in experimentally induced gastric ulcer in rats. Biomed Res 2009; 20: 35-39.

Kuete V, Fozing DC, Kapche WFGD, Mbaveng AT, Kuiate JR, Ngadjui BT, Abegaz BM. Antimicrobial activity of the methanolic extract and compounds from Morus mesozygia stem bark. J Ethnopharmacol 2009; 124: 551-5.

Sohn HY, Son KH, Kwon CS, Kwon GS and Kang SS: Antimicrobial and cytotoxic activity of 18 prenylated flavonoids isolated from medicinal plants: Morus alba L., Morus mongolica Schneider, Broussnetia papyrifera (L.) Vent, Sophora flavescens Ait and Echinosophora koreensis Nakai. Phytomedicine 2004; 11: 666-72.

Du J, He ZD, Jiang RW, Ye WC, Xu HX and But PP: Antiviral flavonoids from the root bark of Morus alba L. Phytochemistry 2003; 62: 1235-8.

Park KM, You JS, Lee HY, Baek NI, Hwang JK. Kuwanon G: an antibacterial agent from the root bark of Morus alba against oral pathogens. J Ethnopharmacol 2003; 84: 1815.

Fukai T, Kaitou K, Terada S. Antimicrobial activity of 2- arylbenzofurans from Morus species against methicillin-resistant Staphylococcus aureus. Fitoterapia 2005; 76: 708-11.

Vitthalrao B. Khyade; Vivekanand V. Khyade and Sunanda V. Khyade (2013): Use of Moracin in preventing the cancer. Journal Of Environmental Science, Toxicology And Food Technology (IOSR-JESTFT) eISSN:2319-2402,p- ISSN: 2319-2399. Volume 4, Issue 5 (May. - Jun. 2013), PP 96104 www.Iosrjournals.Org

Vitthalrao B. Khyade;Vivekanand V. Khyade; Sunanda V. Khyade and May-Britt Moser (2014). Influence of Moracin on DMBA-TPA induced skin tumerigenesis in the mouse. International Journal of Bioassays 3 (11): $3510-3516$. ISSN: 2278-778X. www.ijbio.com

Vitthalrao B. Khyade and Sadhana D. Deshpande 
(2015). Chemopreventive Efficacy Of Ethanolic Extractives Of Leaves Of Mulberry, Morus alba (L) On 7, 12-Dimethylbenz Anthracene (DMBA) Induced Buccal Pouch Carcinoma In Syrian Hamster, Mesocricetus auratus $(\mathrm{L})$. International Journal of Recent Scientific Research, Vol. 6, Issue, 3, pp.31563161, March, 2015. www.recent scientific.com

Vitthalrao B. Khyade; Suryakant M. Mundhe and Shakir Ali Syed (2015). Influence of Ethanolic Extractives of Leaves of Mulberry, Morus alba (L) On 7, 12-Dimethylbenz (A) Anthracene (DMBA) Induced Buccal Pouch Carcinoma in Syrian Hamster, Mesocricetus auratus (L). IOSR Journal of Pharmacy and Biological Sciences (IOSR-JPBS) e-ISSN: 2278-3008, p-ISSN: 2319- 7676. Volume 10, Issue 1 Ver. IV (Jan -Feb. 2015), PP 6975www.iosrjournals.org

Vitthalrao B. Khyade; Shubhangi Shankar Pawar and Rajashri V. Khyade (2018). Oxidative Stress Reducing capabilities of Moracin, The Novel Compound From the Fruits of Mulberry, Morus alba (L) In Hydrogen Peroxide Induced Stress In Skin Fibroblast Cell Line Culture (AH927) International Journal of Scientific Studies Vol. 6, No. 1, 2018, pp. 1-14. ISSN 2348-3008 www.scientificrc.com

Vitthalrao B. Khyade (2018). Influence of Leaf Decoction of Mulberry, Morus alba (L.) on Streptozotocin Induced Diabetes in Brown Rat, Rattus norvegicus (L.). International Journal of Research in Science and Engineering Vol. 6, No. 3, 2018, pp. 1-23.

Conklin D, Gilbertson D, Taft DW, Maurer MF, Whitmore TE, Smith DL, Walker KM, Chen LH, Wattler S, Nehls M, Lewis KB (December 1999). "Identification of a mammalian angiopoietin-related protein expressed specifically in liver". Genomics. 62 (3): 477-82. doi:10.1006/geno.1999.6041. PMID 10644446.

AlissonMacário de Oliveira; Matheus da Silva Mesquita; Gabriela Cavalcante da Silva; Edeltrudes de Oliveira Lima; Paloma Lys deMedeiros; Patrícia Maria Guedes Paiva; Ivone Antônia de Souza and Thiago Henrique Napoleão (2015). Evaluation of Toxicity and Antimicrobial Activity of an Ethanolic Extract from Leaves of Morus alba L. (Moraceae). Hindawi Publishing Corporation
Evidence-Based Complementary and Alternative Medicine Volume 2015, Article ID 513978, 7 pages http://dx.doi.org/10.1155/2015/513978 https://www.hindawi.com/journals/ecam/2015 /513978/ref/

Al-Kirshi, R.A., Alimon, A.R., Zulkifli, I., Sazili, A.O., Zahari, M.W., 2009. The chemical composition and nutritive value of mulberry leaf as a protein source in poultry diets. pp 98-102 in Proc. 1st Int. Seminar on Animal Industry, Bogor Agricultural University, Bogor, Indonesia.

Al-Kirshi, R.A., Alimon, A.R., Zulkifli, I., Sazili, A.O., Zahari, M.W., Ivan, M., 2010. Utilization of mulberry leaf meal (Morus alba) as protein supplement in diets for laying hens. Ital. J. Anim. Sci. 9:e51.

Annison, G., Mughan, P.J., Hendriks, W.H., Bourne, S., 1997. The non-starch polysaccharides of wheat middling by-products. Available from: http://sydney.edu.au/vetscience/apss/ documents/1997/APSS199 7-annisonp244.pdf

AOAC, 2007. Official methods of analysis, 16th ed. Association of Official Analytical Chemists, Washington, DC, USA.

Chowdary, N.B., Rajan, V.M., Dandin, S.B., 2009. Effect of poultry feed supplemented with mulberry leaf powder on growth and development of broilers. IUP Journal of Life Sciences 3:51-54.

D’Mello, J.P.F., Taplin, D.E., 1978. Animal feed. In: F.R. Rushkin (ed.) Leucaena leucocephala in poultry diets for the tropics. National Academy of Sciences Publ., Washington, DC, USA, pp 30-32.

Donkoh, A., Kese, A., Atuahene, C.C., 1990. Chemical composition of chaya leaf meal (Cnidoscolus aconitifolius (Mill.) Johnston) and availability of its amino acids to chicks. Anim. Feed Sci. Tech. 30:155-162. FAO, 1998. Tropical feeds, 8th ed.

FAO Publ., Roma, Italy.

Farhat, A., Normand, L., Chavez, E.R., Touchburn, S.P., 1998. Nutrient digestibility in food waste ingredients for pekin and muscovy ducks. Poultry Sci. 77:1371-1376.

Hill, F.W., Anderson, D.L., 1958. Comparison of metabolizable energy and productive energy determinations with growing chicks. J. Nutr. 64:451-462.

National Research Council, 1994. Nutrient 
requirements of poultry, 9th ed. National Academy Press, Washington, DC, USA.

Olteanu, M., Panaite, T., Ciurescu, G., Criste, R.D., 2010. Effect of the dieters mulberry leaves on layer performance and nutrient digestibility. Proc. 13th Eur. Poultry Conf., Tours, France. Available from: http://epc2010.org/cd/ Abstracts/621.pdf

Omar, S.S., Shayo, C.M., Uden, P., 1999. Voluntary intake and digestibility of mulberry (Morus alba) diets by growing goats. Trop. Grasslands 33:177-181.

Saddul, D., Jelan, Z.A., Liang, J.B., Halim, R.A., 2004. The potential of Morus alba as a fodder crop: The effect of plant maturity on yield, persistence and nutrient composition of plant fractions. Asian Austral. J. Anim. 17:16571662.

Sanchez, M.D., 2002. Mulberry for animal production. Animal Production and Health Paper Series N. 147. FAO Publ., Roma, Italy.

Sarita, S., Rashmi, K., Anju, T., Rajesh, P., 2006. Nutritional quality of leaves of some genotypes of mulberry (Morus alba). Int. J. Food Sci. Nutr. 57:305-313.

Sibbald, I.R., 1979. Passage of food through the adult rooster. Poultry Sci. 58:446-459.

Sibbald, I.R., 1980. The effect of dietary cellulose and sand on the combined metabolic plus endogenous energy and amino acids outputs of adult cockerels. Poultry Sci. 59:836-844.

Smith, O.B., 1994. Using fodder from trees and shrubs to feed livestock in the tropics. Better Farming Series N. 42. FAO Publ., Roma, Italy.

SPSS, 2006. Statistical Package for Social Scientists. SPSS Inc., Chicago, IL, USA.

Thomas, R.L., Sheard, R.W., Moyer, J.R., 1967. Comparison of conventional and automated procedures for nitrogen, phosphorus and potassium analysis of plant material using a single digestion. Agron. J. 59:240- 243.

Van Soest, P.J., Wine, R.H., 1967. Use of detergents in the analysis of fibrous feeds. IV. Determination of plant cell wall constituents. J. Assoc. Off. Ana. Chem. 50:50- 55.

Wang, D.Y., Chen, F., Zhu, Y.Z., Liu, F., Xu, W.M., Zou, C.H., 2011. Effects of mulberry leaf (Folium Mori) powder in hen diets on amino acid composition and texture profiles of egg protein. Fujian J. Agric. Sci. 26:994-996

\section{How to cite this article:}

Rutuja Ashok Kadam, Nivedita Dattatray Dhumal and Vitthalrao Bhimasha Khyade. 2019. The Mulberry, Morus alba (L.): The Medicinal Herbal Source for Human Health. Int.J.Curr.Microbiol.App.Sci. 8(04): 2941-2964. doi: https://doi.org/10.20546/ijcmas.2019.804.341 